\title{
PERAN PENTING DUKUNGAN SOSIAL ORANGTUA TERHADAP KARAKTER SISWA DALAM MENGHADAPI ERA SOCIETY 5.0
}

\author{
Fariz Perdana Putra ${ }^{1}$, Rahma Widyana ${ }^{2}$ \\ Program Studi Magister Psikologi \\ Fakultas Psikologi \\ Universitas Mercu Buana Yogyakarta \\ E-mail:poondutz@gmail.com ${ }^{1}$, umifaqih04@yahoo.com²
}

\begin{abstract}
Abstrak
Membentuk karakter anak dalam menghadapi era society 5.0 khususnya dalam bidang pendidikan bukanlah suatu hal yang mudah untuk dilakukan. Adanya perkembangan didalam bidang teknologi mengharuskan siswa untuk selektif dan bijak dalam menggunakan teknologi dengan tujuan supaya anak dapat menghadapi era societey 5.0. Dukungan sosial dari orangtua memiliki peranan yang penting dalam membentuk karakter siswa untuk menghadapi era society 5.0 .
\end{abstract}

Kata kunci: dukungan sosial orangtua, karakter anak

\begin{abstract}
Shaping the character of children in the face of society era 5.0 especially in the field of education is not an easy thing to do. The existence of developments in the field of technology requires students to be selective and wise in using technology with the aim that children can face the era of societey 5.0. Social support from parents has an important role in shaping the character of students to face the era of society 5.0.
\end{abstract}

Keywords: parental social support, children's character

Info Artikel

Diterima Februari 2020, disetujui Maret 2020, diterbitkan Juni 2020 


\section{PENDAHULUAN}

Keluarga merupakan salah satu komponen inti dalam proses membentuk karakter anak. Hal tersebut dikarenakan keluarga mampu memberikan bekal pertama yang bersifat alamiah dengan tujuan untuk mempersiapkan generasi milineal khususnya di era society 5.0.

Adapun fungsi keluarga dalam membentuk karakter anak memiliki peranan yang begitu penting salah satunya yaitu dalam mempersiapkan nilai-nilai yang positif bagi tumbuh kembang anak sehingga dapat menciptakan fondasi pendidikan untuk kedepannya bagi anak (Mansur, 2005). Selain itu keluarga juga berperan sebagai lembaga pendidikan yang memiliki fungsi yang cukup penting dalam membentuk kepribadian, sosial, sikap keagamaan anak (Baharun, 2016). Sehingga dengan adanya keluarga dalam proses membentuk karakter anak di era society 5.0 diharapkan orang tua mampu menghasilkan anak-anak yang dapat tumbuh menjadi pribadi yang unggul, serta mampu bertahan hidup ditengah-tengah masyarakat sekaligus dapat menerima dan mewarisi nilai-nilai kehidupan dan kebudayaan (Jailani, 2014).

Adanya perkembangan dibidang teknologi tidak hanya menyediakan peluang, tetapi juga memberikan tantangan tersendiri bagi generasi milineal. Menurut Wahy (2012) tantang yang terdekat berasal dari anggota keluarga khususnya orangtua yang kurang mengetahui dan memahami bagaimana cara mendidik anak.

Menurut Baharun (2016) keluarga sebagai lembaga pendidikan memiliki fungsi yang cukup penting dalam membentuk kepribadian, sosial, sikap keagamaan anak. Hal tersebut dikarenakan, setiap manusia mempunyai potensi positif untuk berkembang namun pada kenyataan yang ada sebuah potensi yang dimiliki oleh setiap manusia sangat ditentukan oleh lingkungan keluarga terutama dalam menghadapi kemajuan dibidang teknologi di era society 5.0.

Berdasarkan uraian di atas yang telah dijelaskan, maka penulis tertarik untuk mengetahui bagaimana "peran penting dukungan sosial keluarga terhadap karakter anak dalam menghadapi era society $5.0 "$. 


\section{HASIL DAN PEMBAHASAN}

\section{Dukungan Sosial Orang Tua}

Dukungan sosial orangtua menurut Demaray dan Malecki (2002) merupakan persepsi individu dari dukungan umum atau tindakan spesifik yang bersifat mendukung dari orang-orang dalam jaringan sosial. Menurut Barnes, dkk (2006) dukungan sosial orangtua merupakan sikap perilaku orangtua kepada anak atau remaja yang bisa diterima dengan baik oleh anak. Sementara Crane, dkk (2006) mengartikan dukungan sosial orangtua sebagai tingkat penerimaan dan kehangatan dari orangtua ynag ditujukan kepada anaknya, dimana pada umumnya akan memberikan dampak positif pada prestasi belajar anak, self-esteem yang positif dan rendahnya depresi yang dialami oleh anak atau remaja.

\section{Karakter Siswa}

Menurut Philips (dalam Mu'min, 2011) karakter adalah kumpulan tata nilai yang menuju pada suatu sistem yang melandasi pemikiran, sikap, dan perilaku yang ditampilkan. Karakter dimanifestasikan dalam kebiasaan, baik di kehidupan sehari-hari seperti pikiran baik, hati baik, dan tingkah laku yang baik. Muslich (2010) mengartikan karakter adalah cara berpikir dan berperilaku seseorang yang menjadi ciri khas dari tiap individu untuk hidup dan bekerjasama baik dalam keluarga, masyarakat dan negara.

Sedangkan menurut Sarwono (2007) siswa adalah setiap orang yang secara resmi terdaftar untuk mengikuti pelajaran di dunia pendidikan. Menurut Muhaimin, dkk (2005) siswa dilihat sebagai seseorang "subjek didik" yang mana nilai kemanusiaan sebagai individu, sebagai makhluk sosial yang mempunyai identitas moral dan harus dikembangkan untuk mencapai tingkatan optimal dan kriteria kehidupan sebagai manusia warga negara yang diharapkan.

Berdasarkan pendapat para ahli di atas disimpulkan bahwa karakter siswa adalah cara berpikir dan berperilaku seseorang yang menjadi ciri khas setiap makhluk sosial yang mempunyai moral dan harus dikembangkan untuk mencapai tingkatan optimal dan kriteria kehidupan dilingkungan keluarga, masyarakat dan negara. 


\section{Dimensi Psikologis Karakter Siswa}

Mu'in (2011) menyebutkan bahwa dimensi manusia secara psikologis dan sosiologis yang berkaitan dengan terbentuknya karakter pada diri manusia, diantaranya;

1. Sikap seseorang, dalam hal ini merupakan bagian dari karakter, bahkan dianggap cerminan karakter seseorang tersebut. Dalam hal ini, sikap seseorang terhadap sesuatu yang ada didalamnya biasanya menunjukan bagaimana karakter orang tersebut. Semakin baik sikap seseorang maka akan dikatakan orang dengan karakter baik. Sebaliknya, semakin tidak baik sikap seseorang maka akan diaktakan orang tersebut dengan karakter yang tidak baik.

2. Emosi, dalam hal ini merupakan gejala dinamis dalam situasi yang dirasakan manusia disertai dengan efek pada kesadaran perilaku, dan juga merupakan proses fisiologis. Tanpa emosi kehidupan manusia akan terasa hambar karena manusia selalu hidup dengan berfikir dan merasa, dan emosi identik dengan perasaan yang kuat.

3. Kepercayaan, dalam hal ini merupakan komponen kognitif manusia dari sosiopsikologis. Kepercayaan bahwa sesuatu itu "benar" atau "salah" atas dasar bukti, sugesti otoritas, pengalaman, dan intuisi sangatlah penting dalam membangun watak dan karakter manusia. Kepercayaan dalam hal ini memperkukuh eksistensi diri dan memperkukuh hubungan dengan orang lain.

4. Kebiasaan dan Kemauan, dalam hal ini merupakan aspek perilaku manusia yang menetap, berlangsung secara otomatis pada waktu yang lama, tidak direncanakan dan diulang berkali-kali. Sedangkan kemauan merupakan kondiai yang sangat mencerminkan karakter seseorang karena kemauan berkaitan erat dengan tindakan yang mencerminkan perilaku orang tersebut.

5. Konsep Diri (Self-Conception), dalam hal ini merupakan proses konsepsi diri merupakan proses totalitas, baik sadar maupun tidak sadar tentang bagaimana karakter dan diri seseorang dibentuk. Dalam hal ini, konsepsi diartikan sebagai bagaimana "saya" harus membangun diri, apa yang "saya" inginkan dari dan bagaimana "saya" menempatkan diri dalam kehidupan. 
Berdasarkan uraian diatas maka penulis menggambarkan gagasan penulisan kedalam sebuah skema dibawah ini.

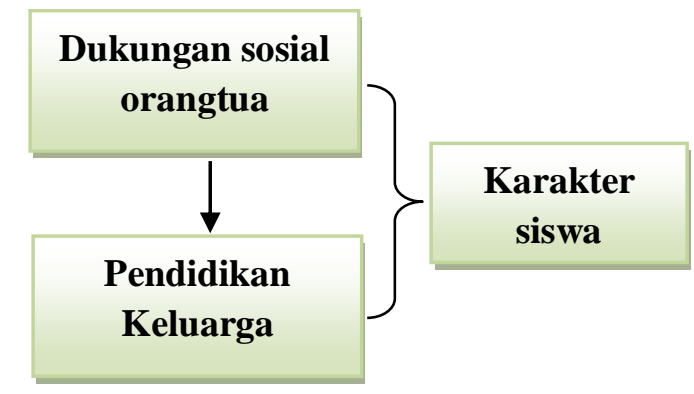

Gambar 1. Gambaran Gagasan Penulisan

Dari skema diatas, dapat diketahui bahwa; Karakter siswa di era society 5.0 akan terbentuk secara efektif melalui dukungan sosial orang tua yang dilakukan melalui metode pendidikan keluarga.

Menurut Omrmord, 2008) salah satu cara untuk menanamkan nilai dan sikap pada anak adalah mendorong anak untuk memiliki kemampuan berfikir tingkat tinggi atau HOTS (Higher Order Thinking Skills). Hal tersebut dikarenakan HOTS adalah kemampuan berpikir kritis, logis, reflektif, metakognitif, dan berpikir kreatif yang merupakan kemampuan berpikir tingkat tinggi.

Keluarga merupakan salah satu hal terpenting dalam pendidikan anak, hal tersebut dikarenakan anak dibesarkan dan dibimbing oleh keluarga. Peran orang tua dalam mendidik anak tidak hanya mengarahkan atau membimbing anak apabila anak mengalami kesulitan saja dalam mencapai tujuan yang diinginkan. Pemilihan cara mendidik yang diterapkan oleh orang tua dalam mengarahkan dan membimbing anak di era society 5.0 harus didasarkan pada perkembangan teknologi yang sudah canggih, dimana orang tua harus beranggapan bahwa anak sudah lebih mahir dalam mencari berbagai informasi sendiri sehingga orangtua berperan untuk mengarahkan anak supaya tidak terjerumus pada hal-hal negatif. Hal tersebut dikarenakan, anak-anak pada generasi masa kini merupakan masa digital native yang berarti mereka sudah mengenal elektronik dan digital sejak lahir. Sehingga dalam proses mendampingi dan membimbing anak orang tua diharapkan mampu melindungi anak-anak dari ancaman era digital, tetapi tidak menghalangi potensi manfaat yang bisa ditawarkan. 
Adapun langkah-langkah yang perlu dilakukan oleh orang tua dalam mendampingi dan membimbing anak sebagai bentuk dukungan sosial dari orang tua kepada anak, menurut Direktorat Pembinaan Pendidikan Keluarga Kementeriaan Pendidikan Dan Kebudayaan (2019), diantaranya;

1. Orang tua harus menambah pengetahuan, dalam hal ini tentunya sulit untuk menetapkan peraturan bila orang tua tidak mengerti apa itu blog atau bagaimana cara menggunakan twitter atau facebook, sehingga orang tua dapa meluangkan waktu untuk melihat situs yang pernah dikunjungi anak.

2. Mengarahkan penggunaan perangkat dan media digital dengan jelas, dalam hal ini jika anak sudah terpapar perangkat digital, orang tua lebih baik untuk mengarahkan dengan komunikasi efektif untuk memutuskan berapa lama dan kapan mereka dapat menggunakannya. Salah satu cara yang dilakukan oleh orang tua yaitu sepakati waktu penggunaan dan waktu untuk berhenti memanfaatkan perangkat media digital dimalam hari.

3. Imbangi waktu menggunakan media digital dengan interaksi di dunia nyata, dalam hal ini orang tua dapat mengimbangi paparan media digital dengan mengenalkan pengalaman dunia nyata seperti aktivitas berkesenian, kegiatan fisik di luar ruangan, olahraga, membaca buku, bermain musik, menari, permainan tradisional dan sebagainya kepada anak.

4. Pilihkan program/aplikasi positif, dalam hal ini orang tua perlu mengidentifikasi program/aplikasi yang memiliki edukasi dan memberikan dampak positif bagi pertumbuhan anak.

5. Mendampingi dan meningkatkan interaksi, dalam hal ini orang tua perlu mendampingi dan berinteraksi dengan anak selama penggunaan media digital, kemudian dampingi anak saat berselancar didunia maya menggunakan satu perangkat digital pada kesempatan yang sama sebagai aktivitas keluarga.

6. Gunakan perangkat digital secara bijaksana, dalam hal ini orang tua perlu memperhatikan batasan usia anak saat anak hendak menggunakan perangkat digital, orang tua perlu bijaksana menggunakan perangkat selama berinteraksi dengan anak. 


\section{KESIMPULAN}

Berdasarkan pembahasan yang telah dilakukan, dapat disimpulkan bahwa; terbentuknya karakter siswa di era society 5.0 dapat terbentuk dengan efektif melalui peran penting dukungan sosial orangtua yang dilakukan melalui metode pendidikan keluarga kepada siswa. Hal tersebut dikarenakan Keluarga merupakan salah satu hal terpenting dalam pendidikan anak, hal tersebut dikarenakan anak dibesarkan dan dibimbing oleh keluarga.

Peran orang tua dalam mendidik anak tidak hanya mengarahkan atau membimbing anak apabila anak mengalami kesulitan saja dalam mencapai tujuan yang diinginkan. Pemilihan cara mendidik yang diterapkan oleh orang tua dalam mengarahkan dan membimbing anak di era society 5.0 harus didasarkan pada perkembangan teknologi yang sudah canggih, dimana orang tua harus beranggapan bahwa anak sudah lebih mahir dalam mencari berbagai informasi sendiri sehingga orangtua berperan untuk mengarahkan anak supaya tidak terjerumus pada hal-hal negatif. Hal tersebut dikarenakan, anak-anak pada generasi masa kini merupakan masa digital native yang berarti mereka sudah mengenal elektronik dan digital sejak lahir. Sehingga dalam proses mendampingi dan membimbing anak orang tua diharapkan mampu melindungi anak-anak dari ancaman era digital, tetapi tidak menghalangi potensi manfaat yang bisa ditawarkan, sehingga karakter anak akan terbentuk efektif sesuai dengan usia perkembangan anak.

\section{DAFTAR PUSTAKA}

Baharu, H. (2016). Pendidikan Anak Dalam Keluarga Telaah Epistemologis. Jurnal Pendidikan, 3 (2) 96-107.

Jailani, M. S. (2014). Teori Pendidikan Keluarga Dan Tanggung Jawab Orang Tua Dalam Pendidikan Anak Usia Dini, 8 (2) 245-260. Jurnal pendidikan islam.

Mansur. (2005). Pendidikan Anak Usia Dini Dalam Islam. Yogyakarta: Pustaka pelajar.

Muhaimin, dkk. (2005). Strategi Belajar Mengajar. Surabaya: Citra Media.

Muslich, M. (2010). Pendidikan Karakter, Menjawab Tantanagn Krisis Multidimensional. Jakarta: Bumi Aksara.

Ormrod, J. E. (2008). Psikologi Pendidikan (Membantu Siswa Tumbuh Dan Berkembang) Edisi 6 Jilid I. Jakarta: Erlangga. 
Sarwono. (2007). Psikologi Remaja. Jakarta: Raja Grafindo Persada.

Wahyu. H. (2012). Keluarga Sebagai Basis Pendidikan Pertama Dan Utama. Jurnal Ilmiah DIDAKTIKA, 12 (2) 245-258. 